\title{
Sorption of pertechnetate anion by cation modified bentonites
}

\author{
D. Buzetzky ${ }^{1}$ - E. M. Kovács ${ }^{1} \cdot$ M. N. Nagy ${ }^{1} \cdot$ J. Kónya $^{1}$
}

Received: 22 July 2019 / Published online: 16 October 2019

(c) The Author(s) 2019

\begin{abstract}
Pertechnetate anion sorption was investigated on modified bentonites. Mn-, Cr-, Sn-bentonites were prepared by ion exchange process to sorb radioactive pertechnetate ions. In the case of Mn-, Cr-bentonite the sorb amount of metal ion was 70-90\% of the cation exchange capacity of the bentonite which is expected. Interestingly in the case of Sn-bentonite this amount was 1.42 times higher than the cation exchange capacity. On Mn-bentonite the sorption was $35 \%$ at $\mathrm{pH} 5$. The removal of pertechnetate ions was $100 \%$ on Cr-, Sn-bentonites and the significant sorption was achieved below $650 \mathrm{mV} / \mathrm{SHE}$.
\end{abstract}

Keywords Pertechnetate ion $\cdot$ Modified bentonite $\cdot$ Redox reaction $\cdot$ Nuclear waste $\cdot$ Sorption

\section{Introduction}

Long-lived low- and medium-level radioactive waste and spent fuel assemblies are difficult to store because fissile products can get into the environment. Natural geological barriers do not bind anions from the fission products of ${ }^{235} \mathrm{U}$ [1]. Among the fission products ${ }^{99} \mathrm{Tc}$ is a $\beta$-emitter, has no stable isotope, has a half-life of $2.13 \times 10^{5}$ years. ${ }^{99} \mathrm{Tc}$ forms by spontaneous fission of ${ }^{238} \mathrm{U}$ in the earth's crust. It is also produced in medical diagnostic uses by the decay of ${ }^{99 \mathrm{~m}} \mathrm{Tc}$ [2]. It is hard to bind, very little is known about its chemistry, but we can assume that it is similar to elements in a column VII B. (e.g., Mn, Re).

In the literature, several methods can be found for the removal of ${ }^{99} \mathrm{Tc}$ in most cases as pertechnetate ions such as ion exchange [3], reductive immobilization [4], adsorption [5], liquid-liquid extractions [6].

Several organic and inorganic, natural and artificial adsorbents was found to remove ${ }^{99} \mathrm{Tc}$ from the environment for example chitosan [7], resins and sponges [3, 8], polymers [9], metal-organic frameworks (MOFs) [10].

In this study we are looking for adsorbents which can be suitable for the construction of waste containers as

D. Buzetzky

dorabeata@science.unideb.hu

1 mre Lajos Isotope Laboratory, Department of Physical Chemistry, University of Debrecen, Egyetem tér 1,

Debrecen 4032, Hungary pertechnetate sorbents. They should be used as an engineering barrier and should be resintance to radioactive radiation.

There are also other adsorbents in the literature such as activated carbon [11, 12], layered double hydroxide (LDHs) [13], alumina and goethite [14], and there are the clay minerals which play an important role in the environment because by removing cations and anions either through ion exchange, adsorption and precipitation, or all these combined, they can act as natural decontaminating agents of numerous pollutants. Bentonite as geological and engineering barrier is present to isolate the radioactive waste deposited in underground disposal and the environment. The main clay mineral of bentonite is montmorillonite, which is a good sorbent because it has a large specific surface area and high cation exchange capacity. Shakira et al. [15], Vinsova, [16] Jedináková-Kř́žová [17]; Jaisi [18]; Milutinović-Nikolić [19], Hamárová [20] dealt with modified clays, for example Vinsova et al. [16] used mixtures of bentonite, bentonite activated carbon, iron powder, $\mathrm{FeSO}_{4}$ and graphite to bind pertechnetate ions.

The main purpose of our work was to prepare Mn-, Cr-, Sn modified bentonites to sorb pertechnetate ions in a high degree. Our work dealt with ${ }^{99} \mathrm{Tc}$, labeled with ${ }^{99 \mathrm{~m}} \mathrm{Tc}$.

Pertechnetate anion sorption was investigated with $\mathrm{Mn}(\mathrm{II}), \mathrm{Sn}(\mathrm{II}), \mathrm{Cr}(\mathrm{III})-\mathrm{TcO}_{4}{ }^{-}$redox reaction. It is assumed that a metal ion with a reducing effect is capable to sorb ${ }^{99 \mathrm{~m}} \mathrm{Tc}(\mathrm{VII})$ ions in the form of $\mathrm{TcO}_{2}$. In this form it can be sorbed.

For example Tc behaves similarly to its manganese chemistry in different reactions. $\mathrm{Mn}(\mathrm{II})$ is capable of redox 
reaction with $\mathrm{Mn}(\mathrm{VII})$ ions to form $\mathrm{Mn}(\mathrm{IV})$. During the permanganometric titration of $\mathrm{Mn}(\mathrm{II})$, a precipitate of $\mathrm{MnO}_{2}$ is formed according to the following equations: (1), (2), (3)

$\mathrm{Mn}^{7+}+3 \mathrm{e}^{-} \rightarrow \mathrm{Mn}^{4+}$

$\mathrm{Mn}^{2+} \rightarrow \mathrm{Mn}^{4+}+2 \mathrm{e}^{-}$

$2 \mathrm{MnO}_{4}^{-}+3 \mathrm{Mn}^{2+}+2 \mathrm{H}_{2} \mathrm{O} \rightarrow 5 \mathrm{MnO}_{2}+4 \mathrm{H}^{+}$

If it is assumed that ${ }^{99 \mathrm{~m}} \mathrm{TcO}_{4}{ }^{-}$ions react similarly to $\mathrm{Mn}$ (II) ions as $\mathrm{MnO}_{4}{ }^{-}$ions, then the radionuclide can theoretically be precipitated in ${ }^{99} \mathrm{TcO}_{2}$ form, thereby it can be sorbed. Our experiences would be interpreted focusing on the $\mathrm{pH}$ and redox potential values that determine the chemistry forms, and on thermodynamic data.

\section{Experimental}

\section{The modification of the cation exchanged bentonites}

Modified bentonites were prepared by cation exchange procedure using Ca-bentonite (Istenmezeje, Hungary) and $\mathrm{Mn}\left(\mathrm{ClO}_{4}\right)_{2} ; \mathrm{Cr}\left(\mathrm{ClO}_{4}\right)_{3} ; \mathrm{SnCl}_{2}$ solutions.

The cation exchange capacity (CEC) of Ca-bentonite determined by ammonium acetate method [21] is $4.1 \times 10^{-4} \mathrm{~mol} \mathrm{~g}^{-1}$ for divalent ions and $2.7 \times 10^{-4} \mathrm{~mol} \mathrm{~g}^{-1}$ for trivalent ions [22]. Chemical composition of the original Ca-bentonite were measured with EDAX. It has the following composition: $73.29 \% \mathrm{SiO} 2,18.71 \% \mathrm{Al}_{2} \mathrm{O}_{3}, 1.48 \%$ $\mathrm{FeO}, 2.29 \% \mathrm{CaO}$ and $4.23 \% \mathrm{MgO}$. The $\mathrm{X}$-ray diffraction and thermoanalytical results are: $71 \mathrm{~m} / \mathrm{m} \%$ montmorillonite, $12 \mathrm{~m} / \mathrm{m} \%$ cristobalite/opal CT, $8 \mathrm{~m} / \mathrm{m} \%$ illite, $4 \mathrm{~m} / \mathrm{m} \%$ quartz, $3 \mathrm{~m} / \mathrm{m} \%$ kaolinite, and $2 \mathrm{~m} / \mathrm{m} \%$ calcite.

$\mathrm{Mn}\left(\mathrm{ClO}_{4}\right)_{2}$ solution was prepared from analytically pure $\mathrm{MnCO}_{3}$ (Reanal). $2.87536 \mathrm{~g} \mathrm{MnCO}_{3}$ was dissolved in $\sim 167 \mathrm{~cm}^{3}$ of $0.3 \mathrm{~mol} \mathrm{dm} \mathrm{dm}^{-3}$ perchloric acid solution. $\mathrm{Cr}\left(\mathrm{ClO}_{4}\right)_{3}$ solution was prepared by the dissolution of $\mathrm{Cr}-$ powder (Alfa Aesar, pur. 99\%) in $2 \mathrm{~mol} \mathrm{dm}^{-3}$ perchloric acid solution. For $\mathrm{SnCl}_{2}$ solution $7 \mathrm{~g}$ of $\mathrm{Sn}$ chips (Reanal, puris.) was dissolved in $10 \mathrm{~cm}^{3} \mathrm{cc} .37 \% \mathrm{HCl}$ solution during heating to $60{ }^{\circ} \mathrm{C}$. The dissolution took 3 days. The concentration of $\mathrm{Mn}\left(\mathrm{ClO}_{4}\right)_{2}$ determined by complexometric titration; and $\mathrm{Cr}\left(\mathrm{ClO}_{4}\right)_{3}, \mathrm{SnCl}_{2}$ solutions determined by MP-AES (Agilent Technologies 4200) were 0.09442; $6.95 \times 10^{-2} ; 1.1 \times 10^{-1} \mathrm{~mol} \mathrm{dm}^{-3}$ respectively.

After preparing the modifying solutions the cation exchange procedure was carried out by suspending equivalent amount of metal-solutions and Ca-bentonite. In the case of Mn-bentonite the mixture was shaken for $5 \mathrm{~h}$, and in the case of $\mathrm{Cr}$ - and $\mathrm{Sn}$-bentonites, due to the low $\mathrm{pH}$ and to avoid the significant destruction of bentonite, the mixture was shaken $3 \times 5 \mathrm{~min}$.

After shaking, the modified bentonites were filtered through a Labex Ltd. $0.45 \mu \mathrm{m}$ pore size nylon bio-filter. The bentonite on the filter was returned to the beaker and the same amount and concentration of solution was added. This operation was repeated two more times. After the third change, the modified bentonites were dried in room temperature and powdered into agate mortar.

The Mn, Cr, Sn concentration of bentonite was determined by X-ray fluorescence analysis (XRF) using tungsten $\mathrm{X}$-ray tube and ${ }^{241} \mathrm{Am}$ isotope source. The parts of XRF were $\mathrm{Si}(\mathrm{Li})$ detector with $20 \mathrm{~mm}^{2}$ surface and $3.5 \mathrm{~mm}$ evaporated layer (Atomki, Debrecen, Hungary), Canberra DSA 1000 digital spectrum analyzer (Canberra Industries, Meriden, CT 06450, USA) and Canberra Genie 20003.0 spectroscopy software.

The d(001) basal spacing of the initial Ca-montmorillonite and the Mn-, Cr-, Sn-montmorillonites were determined with X-ray diffraction (XRD). The parts and settings of XRD are the following: a Philips PW1710 powder diffractometer equipped with a $\mathrm{CuK} \alpha$ source and a graphite monochromator (operating at $30 \mathrm{~mA}, 40 \mathrm{kV}$ ). The scan rate was $2^{\circ} 2 \Theta / \mathrm{min}$.

\section{Pertechnetate ion sorption kinetic on modified bentonites}

The sorption kinetic of ${ }^{99 \mathrm{~m}} \mathrm{TcO}_{4}{ }^{-}$(Drytec $2.5-100 \mathrm{GBq}$ radioactive isotope generator) was studied in batch experiments. $25 \mathrm{~cm}^{3}$ physiological $\mathrm{NaCl}$ solution was used to eluate the isotope from the generator (Drytec $2.5-100 \mathrm{GBq}$ ). $100 \mathrm{mg}$ modified-bentonite was added to $19 \mathrm{~cm}^{3}$ distilled water. All samples were placed in a Bühler KS15A shaking bath at $25^{\circ} \mathrm{C}$ for $30 \mathrm{~min}$ to reach the equilibrium between the liquid and the solid phase. After this time, $1 \mathrm{~cm}^{3}{ }^{99 \mathrm{~m}} \mathrm{TcO}_{4}{ }^{-}$solution was added to the samples. All samples were shaken for 5-120 min then filtered through a Labex Ltd. $0.45 \mu \mathrm{m}$ pore size nylon bio-filter and the radioactive intensity of the solution $\left(c_{\mathrm{e}}\right)$ and the solid phase was measured with a multi-channel gamma spectrometer equipped with (NaI)Tl scintillation detector, it had to be calibrated due to the different geometry of the solid and solution samples. $\mathrm{pH}$ of the solution was measured with a Clean $\mathrm{pH} 200 \mathrm{pH}$ meter and a Clean Cs1030 combined glass electrode.

The redox potential was measured using a platinum electrode and a calomel reference electrode containing $1 \mathrm{~mol} \mathrm{dm}^{-3} \mathrm{KCl}$ solution. The measured redox potentials were converted to potentials measured against a standard hydrogen electrode (SHE). The measurement was needed to determine the oxidation state of the ${ }^{99 \mathrm{~m}} \mathrm{Tc}$ ion in the solution based on the potential-pH diagram.

The pertechnetate ion sorption was investigated on Mn-bentonite at different $\mathrm{pH}$ values $(3.5 ; 4.5 ; 5)$ on $\mathrm{Cr}$-, 
Sn-bentonites without adjusting the $\mathrm{pH}$. The $\mathrm{pH}$ values were 4.5 for $\mathrm{Cr}$-bentonite and 3.1 for $\mathrm{Sn}$-bentonite. The sorption was determined at room temperature.

\section{Results and discussion}

\section{Characterization of modified bentonites}

The $\mathrm{Mn}, \mathrm{Cr}$, Sn concentrations in modified bentonites were $7 \times 10^{-4} ; 1.86 \times 10^{-4} 5.8 \times 10^{-4} \mathrm{~mol} \mathrm{~g}^{-1}$, so 0.860 .69 and 1.42 times of the cation exchange capacity was sorbed in bentonite, respectively.

$\mathrm{X}$-ray diffractograms of the modified bentonites as well as the initial Ca-bentonite are shown in Fig. 1. The structure of the bentonites were not damaged, just the same peaks are shown. Table 1 shows that after modification with $\mathrm{Cr}$ and
Table 2 Results of pertechnetate ion sorption on Mn-, Cr-, Sn-modified bentonites, average result of $5-120 \mathrm{~min}$; $100 \mathrm{mg}$ bentonite, $20 \mathrm{~cm}^{3}$ solution

\begin{tabular}{llll}
\hline Ion & $\mathrm{pH}$ & $\begin{array}{l}\text { Relative sorbed quantity } \\
\text { of Tc }(\%)\end{array}$ & $\begin{array}{l}\text { Redox poten- } \\
\text { tial (mV/SHE) }\end{array}$ \\
\hline $\mathrm{Mn}$ & $3.5-3.6$ & $16 \pm 2$ & $874 \pm 17$ \\
& $4.6-4.7$ & $25 \pm 1$ & $679 \pm 39$ \\
& 5 & $35 \pm 1$ & $558 \pm 59$ \\
$\mathrm{Cr}$ & 4.5 & $100 \pm 0.004$ & $633 \pm 21$ \\
$\mathrm{Sn}$ & 3.1 & $100 \pm 0.1$ & $560 \pm 15$ \\
\hline
\end{tabular}

Sn the d(001) basal spacing of montmorillonites decreased, because the ionic radii of the metal ions (Table 1) are less than that of Ca-ion. In the case of Mn-bentonite, the $\mathrm{d}(001)$ basal spacing of montmorillonite is the same as Ca-bentonite, because there is no big difference in ionic radii and

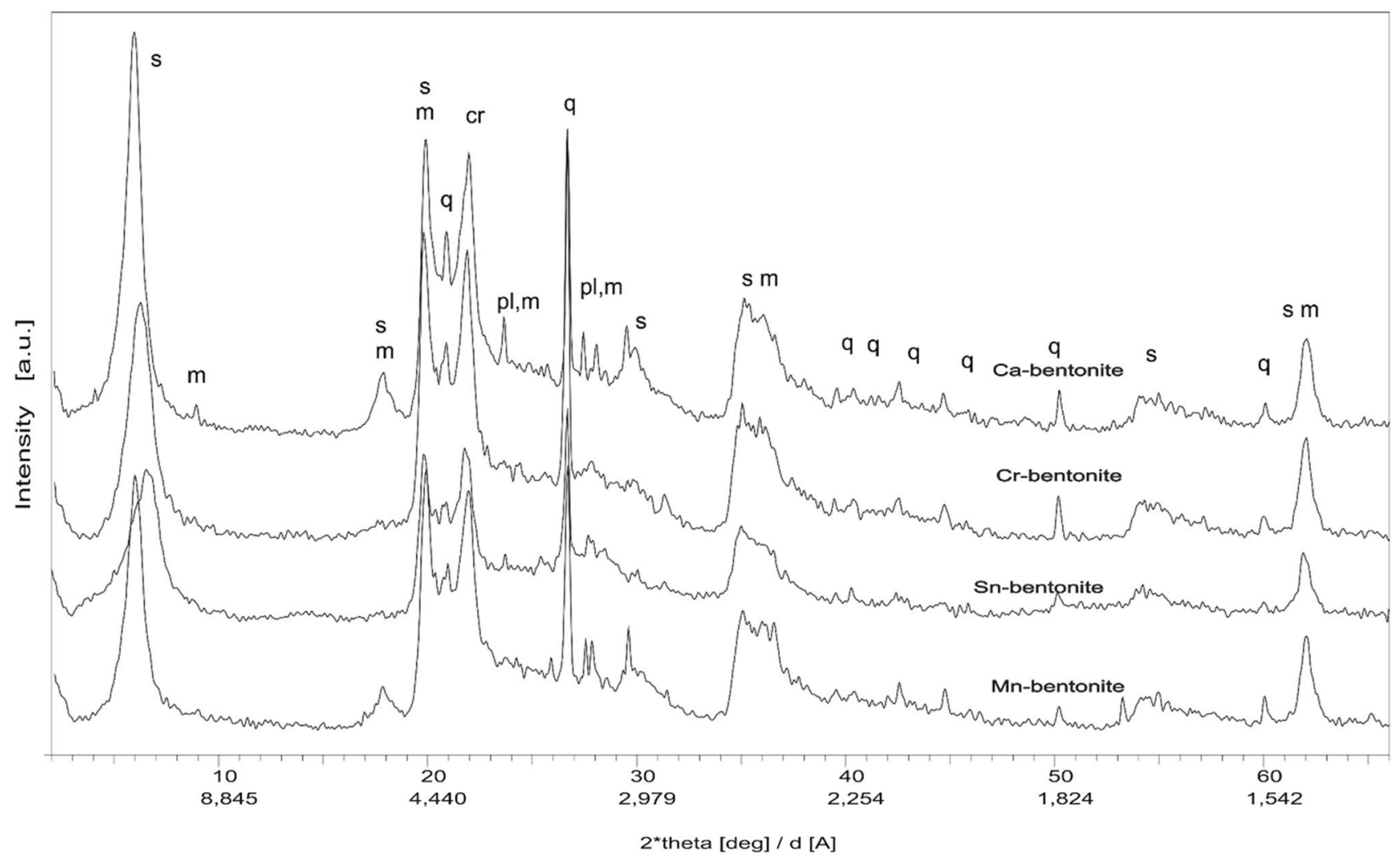

Fig. 1 XRD spectrum of $\mathrm{Ca}$ - and the modified; the unit of y axis is arbitrary unit (a.u.) ( $m$ mica, $p l$ plagioclase, $s$ smectite, $c r$ cristobalite, $q$ quartz)

Table 1 The d(001) basal spacing of Ca-, Mn-, Cr-, Sn-bentonites

\begin{tabular}{lllll}
\hline & Ca-bentonite & Mn-bentonite & Cr-bentonite & Sn-bentonite \\
\hline $\mathrm{d}(001)$ basal spacing $(\mathrm{nm})$ & 1.477 & 1.477 & 1.412 & 1.351 \\
Ionic radii $(\mathrm{nm})$ & $\mathrm{Ca}$ & $\mathrm{Mn}$ & $\mathrm{Cr}$ & $\mathrm{Sn}$ \\
& 0.114 & 0.08 & 0.0755 & 0.069 \\
\hline
\end{tabular}




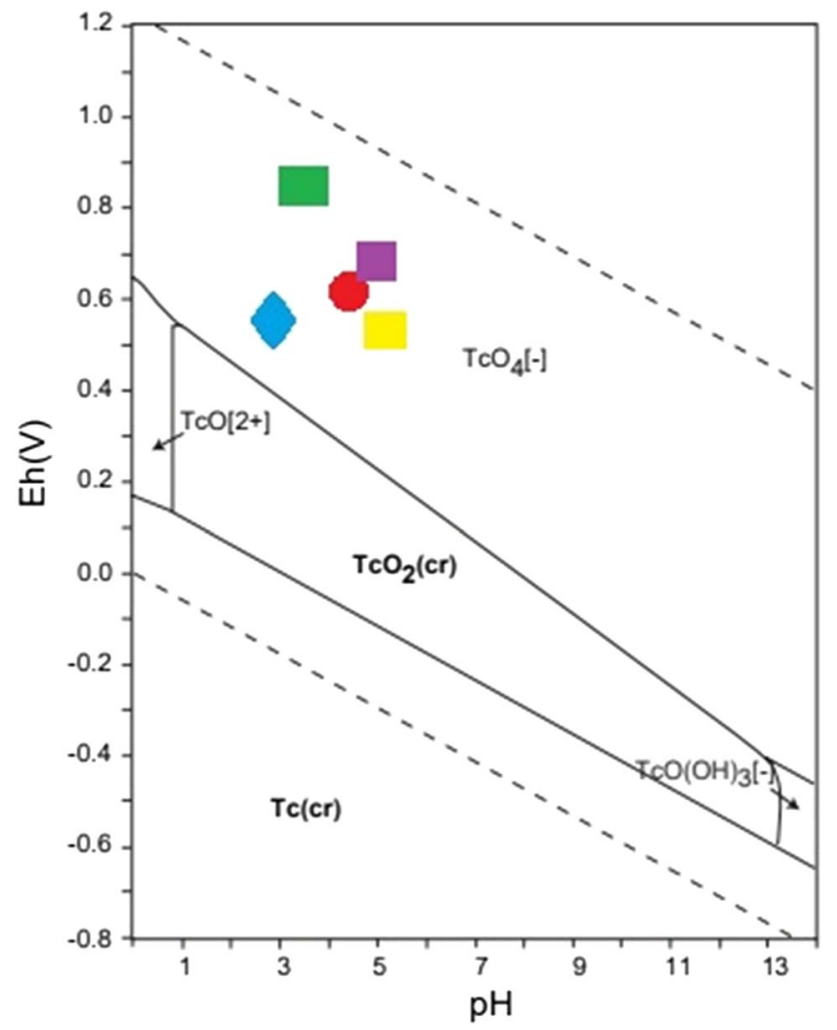

Fig. 2 The pH-Eh predominance diagrams for the sorption of technetium (Mn-bentonite: green square $\mathrm{pH}$ 3.5-3.6; violet square $\mathrm{pH} 4.6-$ 4.7 yellow square $\mathrm{pH} 5$; Cr-bentonite: red circle $\mathrm{Sn}$-bentonite: blue diamond). (Color figure online)

$\mathrm{Ca}$ and $\mathrm{Mn}$ are bivalent ions, so they coordinate the same number of water molecules.

\section{Results of sorption experiments}

Table 2 shows the average results of 5-120 min sorption of pertechnetate ion on $100 \mathrm{mg}$ modified bentonites. On Mnbentonite, the $\mathrm{pH} 5$ of the three $\mathrm{pH}$ ranges was the most effective, approx. 35\%. Kinetics was so fast that there is an equilibrium after $5 \mathrm{~min}$. Based on the results it can be concluded that the relative sorbed amount of pertechnetate ions was approx. $100 \%$ after 5 min on $\mathrm{Cr}$-, Sn-bentonite.

Pourbaix diagram show the electrochemical stability for different redox states of an element as a function of $\mathrm{pH}$. Figure 2 shows the Pourbaix diagram of Tc on which are summarized our experimental results. The colored shapes indicate the modified bentonites and their associated $\mathrm{pH}$ values. The straight lines refers to equilibrium between Tc species. In the case of Mn-bentonite with increasing sorption, the potential values are approaching the $\mathrm{TcO}_{2}$ state. In the case of $\mathrm{Cr}-, \mathrm{Sn}$-bentonites the measured redox potential values do not fall into the region of $\mathrm{Tc}(\mathrm{IV})$ oxidation sate despite the $100 \%$ sorption, but in all cases the dominant chemical form is pertechnetate. Figure 2 shows information only about the chemical species typical of technetium, but not only Tc ions are present in this solution. It is possible that a part of the modifying ions (manganese, chromium, tin) desorbed from the surface, e.g., by exchange with the hydrogen ions in the solution. Since the concentration of Tc is small (cca. $10^{-15}$ $\left.\mathrm{mol} / \mathrm{dm}^{3}\right)$, the concentration of manganese, chromium, tin ions can significantly exceed it. Thus the redox potential does not provide information about the oxidation state of Tc, but rather the oxidation state of the modifying metal ions and this state is taken by the Tc. So we have to consider the Pourbaix diagram of the metals in each case. Figure 3 shows
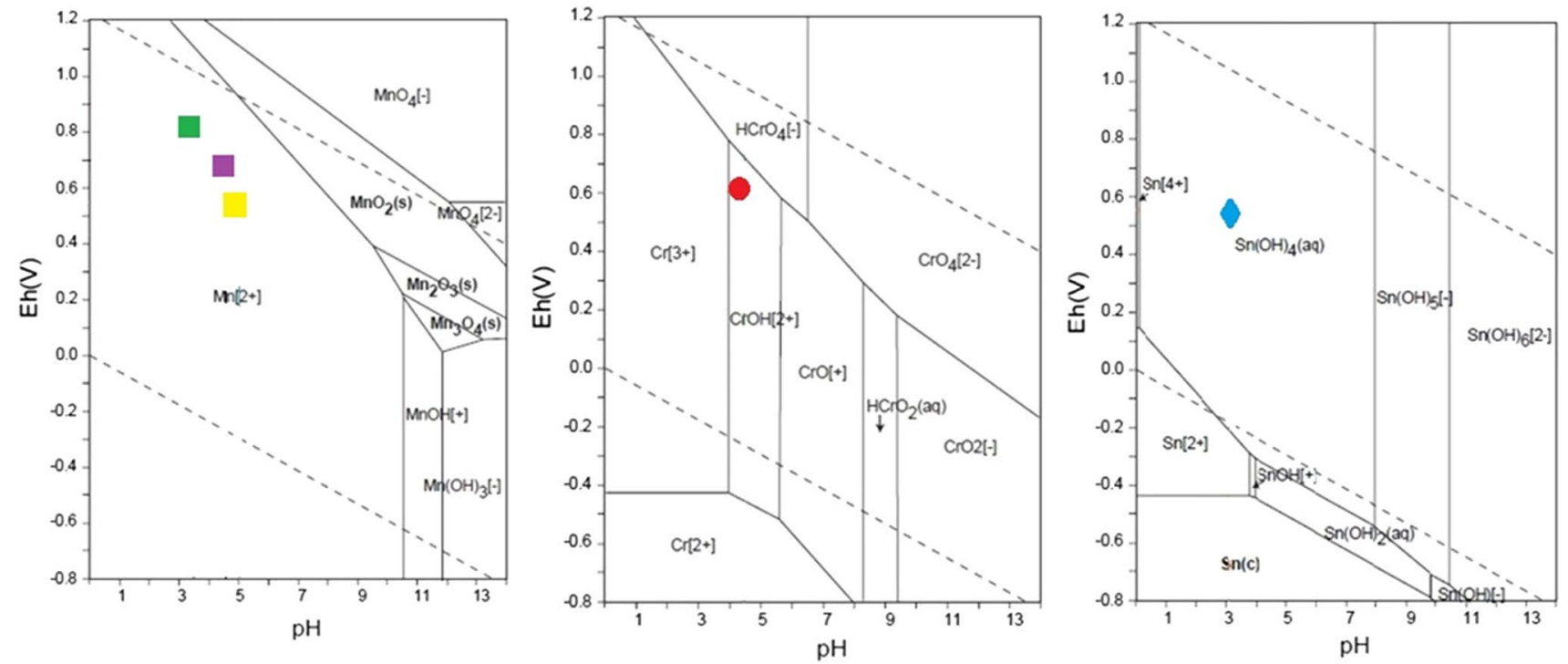

Fig. 3 The pH-Eh predominance diagrams for $\mathrm{Mn}, \mathrm{Cr}$, $\mathrm{Sn}$ (Mn-bentonite: green square $\mathrm{pH}$ 3.5-3.6; violet square $\mathrm{pH} 4.6-4.7$ yellow square $\mathrm{pH}$ 5; Cr-bentonite: red circle Sn-bentonite: blue diamond). (Color figure online) 
Table 3 Comparison of literary data of technetium removal

\begin{tabular}{|c|c|c|c|c|c|}
\hline Adsorbent & Tc removal (\%) & Species & Contact time ( $\mathrm{min})$ & $\mathrm{pH}$ & Reference \\
\hline $\begin{array}{l}\text { Activated carbon } \\
\text { mixed bentontie }\end{array}$ & 80 & $\mathrm{TcO}_{4}^{-}$ & 10 & & [16] \\
\hline Activated carbon & 99 & $\mathrm{TcO}_{4}^{-}$ & Few minutes & & [12] \\
\hline COY zeolite & $\begin{array}{l}95 \\
98.8\end{array}$ & $\mathrm{TcO}_{2}$ & $\begin{array}{l}30 \\
1440\end{array}$ & 2.5 & {$[5]$} \\
\hline Activated carbon & $\sim 100$ & $\mathrm{TcO}_{4}^{-}$ & 30 & & [11] \\
\hline Sn-apatite & $>92$ & $\mathrm{TcO}_{4}^{-}$ & & 5 & {$[20]$} \\
\hline Cr-bentonite & 100 & $\mathrm{TcO}_{4}^{-}$ & 5 & 4.5 & This study \\
\hline Sn-bentonite & 99.94 & $\mathrm{TcO}_{4}^{-}$ & 5 & 3.1 & This study \\
\hline
\end{tabular}

that in all three cases, the dominant chemical species are dissolved species, so it can be assumed that they also effect the measured redox potential values.

On the Pourbaix diagram of $\mathrm{Sn}$ it can be seen that $\mathrm{Sn}$ is in +4 oxidation state and preliminary Mössbauer-measurements indicate the +4 oxidation state. The +2 oxidation state also appears to a lesser extent. Thus, $\mathrm{Sn}$ ions are assumed to be present in +2 oxidation state in the interlayer space of the bentonite, and on the surface $\mathrm{Sn}$ ions are precipitated in +4 oxidation state, this explains the sorption over the cation exchange capacity of bentonite (1.42 times of CEC). From the $\mathrm{pH}-\mathrm{Eh}$ predominance diagrams coprecipitation is assumed.

Our results correlate well with literature data (Table 3). Vinsova et al. [16] examined bentonite mixtures to remove pertechnetate ions. Bentonite-graphite and bentonite-FeSO mixtures showed negligible sorption capacity, while bentonite showed less than $15 \%$. Greater sorption was achieved with iron powder and activated carbon mixed bentonites. In both cases a soprtion of 80-90\% was observed. Almost $100 \%$ soprtion was achieved after 30 min on activated carbon [12]. On Sn-apatite $>92 \%$ removal of technetium was observed [20]. Hercigonja et al. [5] used several types of zeolites for technetium removal. In this study firstly Tc(VII) was reduced to $\mathrm{Tc}(\mathrm{IV})$ with $\mathrm{SnCl}_{2}$ and then adsorbed. COY $\left(\mathrm{Co}^{2+}\right.$ was introduced into the zeolite) zeolite could adsorb $95 \%$ of $\mathrm{TcO}_{2}$ after $30 \mathrm{~min}$ and $98.8 \%$ after $1440 \mathrm{~min}$. The advantage of our adsorbent compared to literature is that it can sorb technetium very fast with high efficiency without reducing.

\section{Conclusion}

Mn-, Cr-, Sn cation modified bentonite were prepared from Ca-bentonite. These modified bentonites were used for pertechnetate ion removal.

From the redox potential and relative sorption values, it can be seen that the sorption on Mn-bentonite was the most effective at pH 5, approx. 35\%. On Cr-, Sn-modified bentonites the removal of Tc was $100 \%$ after 5 min. According to the results found in the literature the studied modified bentonites are suitable for faster and large-scale sorption of ${ }^{99 \mathrm{~m}} \mathrm{Tc}$ ions.

$\mathrm{Cr}$ - and $\mathrm{Sn}$-bentonites can be suitable for the construction of waste containers as pertechnetate sorbents.

Acknowledgements Open access funding provided by University of Debrecen (DE). The authors thank Peter Konya for the X-ray diffraction measurements, Ernô Kuzmann for Mössbauer measurements. The research was supported by the EU and co-financed by the European Regional Development Fund under the project GINOP-2.3.2-15-201600008. The work was supported by the Hungarian National Research, Development, and Innovation Office (NKFIH K 120265).

Open Access This article is distributed under the terms of the Creative Commons Attribution 4.0 International License (http://creativeco mmons.org/licenses/by/4.0/), which permits unrestricted use, distribution, and reproduction in any medium, provided you give appropriate credit to the original author(s) and the source, provide a link to the Creative Commons license, and indicate if changes were made.

\section{References}

1. Prăvălie R (2014) Nuclear weapons tests and environmental consequences: a global perspective. Ambio 43(6):729-744. https://doi.org/10.1007/s13280-014-0491-1

2. Larsen IL, Stetar EA, Glass KD (1995) In-house screening for radioactive sludge at a municipal wastewater treatment plant. Radiat Prot Manag 12(41):29

3. Sarri S, Misaelides P, Zamboulis D, Gaona X, Altmaier M, Geckeis H (2016) Rhenium(VII) and technetium(VII) separation from aqueous solutions using a polyethylenimine-epichlorohydrin resin. J Radioanal Nucl Chem 307(1):681-689

4. Lenell BA, Arai Y (2017) Perrhenate sorption kinetics in zerovalent iron in high $\mathrm{pH}$ and nitrate media. J Hazard Mater 321:335-343

5. Hercigonja RV, Vranješ-Djurić SD, Mirković MD, Marković BM, Maksin DD, Marković BN, Nastasović AB (2018) Technetium removal from the aqueous solution using zeolites $\mathrm{A}$ and $\mathrm{Y}$ containing transition metal ions $\mathrm{Co}^{2+}$ and $\mathrm{Zn}^{2+}$. J Radioanal Nucl Chem 317(1):215-225

6. Stepinski DC, Vandegrift GF, Shkrob IA, Wishart JF, Kerr K, Dietz ML, Qadah DTD, Garvey SL (2010) Extraction of 
tetra-oxo anions into a hydrophobic, ionic liquid-based solvent without concomitant ion exchange. Ind Eng Chem Res 49:5863-5868

7. Pivarčiová L, Rosskopfová $\mathrm{O}$, Galamboš $\mathrm{M}$, Rajec $\mathrm{P}$, Hudec $\mathrm{P}$ (2015) Sorption of pertechnetate anions on chitosan. J Radioanal Nucl Chem 308(1):93-98

8. Nash C, Musall B, Morse M, McCabe D (2015) Characterization of SuperLig 639 rhenium and technetium resin with batch contact and column tests. Sep Sci Technol 50(18):2881-2887

9. Chen J, Veltkamp AC (2002) Pertechnetate removal by macroporous polymer impregnated with 2-nitrophenil octyl ether (NPOE). Solvent Extr Ion Exch 20(4-5):515-524

10. Banerjee D, Xu W, Nie Z, Johnson LE, Coghlan C, Sushko ML, Kim D, Schweiger MJ, Kruger AA, Doonan CJ, Thallapally PK (2016) Zirconium-based metal-organic framework for removal of perrhenate from water. Inorg Chem 55(17):8241-8243

11. Popova NN, Bykov LG, Petukhova AG, Tananaev GI, Ershov GB (2013) Sorption of Tc(VII) and Am(III) by carbon materials: effect of oxidation. J Radioanal Nucl Chem 298:1463-1468

12. Daňo M, Viglašová E, Galamboš M et al (2017) Sorption behavior of pertechnetate on oxidized and reduced surface of activated carbon. J Radioanal Nucl Chem 314:2219-2227

13. Sheng G, Tang Y, Linghu W, Wang L, Li J, Li H, Wang X, Huang $\mathrm{Y}$ (2016) Enhanced immobilization of $\mathrm{ReO}_{4}{ }^{-}$by nanoscale zerovalent iron supported on layered double hydroxide via an advanced XAFS approac: implications for $\mathrm{TcO}_{4}{ }^{-}$sequestration. Appl Catal B 192:268-276

14. Kumar S, Rawat N, Kar AS, Tomar BS, Manchanda VK (2011) Effect of humic acid on sorption of technetium by alumina. J Hazard Mater 192:1040-1045

15. Shakira K, Ghoneimya HF, Hennawyb IT, Elkafrawyc AF, Beheira SGE, Refaata M (2011) Simultaneous removal of chromotrope
$2 \mathrm{~B}$ and radionuclides from mixed radioactive process wastewater using organo-bentonite. Eur J Chem 2:83-93

16. Vinsova H, Konirova R, Koudelkova M, Jedinakova-Krizova V (2004) Sorption of technetium and rhenium on natural sorbents under aerobic conditions. J Radioanal Nucl Chem 261(2):407-413

17. Jedináková-Křížová V, Zeman J, Vinšová H, Hanslík E (2010) Bentonite stability, speciation and migration behaviour of some critical radionuclides. J Radioanal Nucl Chem 286:719-727

18. Jaisi DP, Dong H, Plymale AE, Fredrickson JK, Zachara JM, Heald S, Liu C (2009) Reduction and long-term immobilization of technetium by $\mathrm{Fe}(\mathrm{II})$ associated with clay mineral nontronite. Chem Geol 264(127-138):4

19. Milutinović-Nikolić A, Maksin D, Jović-Jovičić N, Mirković M, Stanković D, Mojović Z, Banković P (2014) Removal of ${ }^{99} \mathrm{Tc}(\mathrm{VII})$ by organo-modified bentonite. Appl Clay Sci 95:294-302

20. Hamárová A, Rosskopfová O (2018) Characterization of Sn-Apatites and ${ }^{99 \mathrm{~m}} \mathrm{TcO}_{4}{ }^{-}$anions removal from aqueous solutions. Acta Chim Slov 11(1):68-73

21. Richards LA (ed) (1957) Diagnosis and improvement of saline and alkali soils. United States Department of Agriculture, Washington

22. Kovács EM, Erdélyiné Baradács E, Kónya P, Kovács-Pálffy P, Harangi S, Kuzmann E, Kónya J, Nagy NM (2017) Preparation and structure's analyses of lanthanide( $\mathrm{Ln}$ )-exchanged bentonites. Colloids Surf A 522:287-294

Publisher's Note Springer Nature remains neutral with regard to jurisdictional claims in published maps and institutional affiliations. 